\title{
ABSORPTION METHOD FOR NEUTRALIZATION OF SULFUR DIOXIDE
}

\author{
Kuznyetsov S.I., Ischenko D.R. \\ Kherson National Technical University \\ Beryslavske highway, 24, 73008, Kherson \\ ksieko@rambler.ru \\ mnenflint@gmail.com
}

\begin{abstract}
A method is proposed for cleaning waste gas from heat-and-power enterprises from sulfur dioxide. The influence of various physicochemical factors on the absorption process has been studied. Optimal parameters were determined and a mathematical model of the process was obtained. In parallel, some parameters of wastewater neutralization were investigated. Key words: absorption, purification of waste gases, neutralization of sulfur dioxide.
\end{abstract}

Абсорбційний метод нейтралізації двооксиду сірки. Кузнсцов С.І., Іщенко Д. У статті запропоновано метод очищення відведених газів теплоенергетичних підприємств від двооксиду сірки. Вивчено вплив різних фізико-хімічних факторів на процес абсорбції. Визначено оптимальні параметри й отримано математичну модель процесу. Паралельно досліджено деякі параметри нейтралізації стічних вод. Ключові слова: абсорбція, очищення відведених газів, нейтралізація двооксиду сірки.

\begin{abstract}
Абсорбционный метод нейтрализации диоксида серы. Кузнецов С.И., Ищенко Д. В статье предложен метод очистки отходящих газов теплоэнергетических предприятий от диоксида серы. Изучено влияние различных физико-химических факторов на процесс абсорбции. Определены оптимальные параметры и получена математическая модель процесса. Параллельно исследованы некоторые параметры нейтрализации сточных вод. Ключевые слова: абсорбция, очистка отходящих газов, нейтрализация диоксида серы.
\end{abstract}

All human life passes in the air. A person continuously consumes about $15-20 \mathrm{~m}^{3}$ of air per day [1]. Air pollution even in small doses can cause serious damage to people's health. Polluted air can destroy ecological bonds in nature. This leads to heavy and unforeseen consequences.

Worldwide emissions of sulfur dioxide to the atmosphere amount to 190 million tons per year [2]. It is a colorless gas with a strong odor, which is formed during the combustion of sulfur-containing fossil fuels. Prolonged exposure to sulfur dioxide in humans leads to loss of taste, cramped breathing, inflammation or pulmonary edema. It contributes to interruptions in cardiac activity, impaired blood circulation and respiratory arrest [3].

Combining in an atmosphere with water vapor, sulfur oxides form sulfuric, sulfurous acid [4]. Then, acid rain in the soil makes it acidic, reducing the yield of agricultural crops. Acid rain affects the leaves of plants and there are "burns" in the form of brown spots. Trees lose some foliage and become defenseless against frost and disease. As a result of chemical reactions, the soil loses some trace elements and becomes less nutritious. Restoration of fertility of acidic soils requires large material costs.

Acid rain has a negative effect on reservoirs - lakes, rivers, bays, ponds - increasing their acidity. Algae grow best in water with a $\mathrm{pH}$ between 7 and 9.2. With an increase in acidity, they die, depriving other animals of the reservoir of food. With a $\mathrm{pH}$ of 6 , freshwater shrimp die. When the acidity rises to $\mathrm{pH} 5.5$, bottom bacteria die, which decompose organic matter and leaves, and organic debris begins to accumulate at the bottom. Then plankton perishes, which forms the basis of the food chain of water bodies and feeds on substances formed during the decomposition of organic substances by bacteria. When the acidity reaches a $\mathrm{pH}$ of 4.5 , all fish, most frogs and insects, die [5].

As organic matter accumulates at the bottom of water bodies, toxic metals begin to leach out of them. The increased acidity of water contributes to a higher solubility of such dangerous metals as aluminum, cadmium, mercury, and lead from bottom sediments and soils. These heavy metals are hazardous to human health.

A great damage to the economy is caused by the corrosion of metals, which is accelerated under the action of air containing sulfur dioxide. Due to corrosion, millions of tons of ferrous metals are lost every year, of which complex and expensive engineering structures are complex: bridges, towers for energy transmission, pipelines. And under the influence of atmospheric pollution, the destruction of buildings, monuments of architecture and art occurs. Acid rain can dissolve the mortar in the masonry of buildings, damage structures made of natural stone, especially limestone, which in turn can lead to loss of strength of structures.

For industrial purification of waste gases from sulfur dioxide, it is advisable to use absorption methods. Of great importance is the correct choice of the absorption solution. 
Absorption is the process of selective absorption of gas by a liquid. Two phases are involved in absorption processes - liquid and gas. When this occurs, the transition of the substance from the gas phase to the liquid. Absorption processes are one of the types of mass transfer.

There are physical absorption and chemisorption. During physical absorption, the gas is retained in the liquid due to mechanical (physical) bonds and it is not accompanied by a chemical reaction. During chemisorption, a chemical reaction takes place between the components [6].

The basis of absorption is diffusion processes of transition of a substance from the gaseous phase to the liquid through the interface. The driving force of absorption is the difference between the initial and equilibrium pressures of the interacting components:

$$
\Delta \mathrm{Pcp}=\frac{\left(\mathrm{P}_{\mathrm{r}}^{\prime}-\mathrm{P}_{\mathrm{p}}^{\prime}\right)-\left(\mathrm{P}_{\mathrm{r}}^{\prime \prime}-\mathrm{P}_{\mathrm{p}}^{\prime \prime}\right)}{2,3 \lg \frac{\mathrm{P}_{\mathrm{r}}^{\prime}-\mathrm{P}_{\mathrm{p}}^{\prime}}{\mathrm{P}_{\mathrm{r}}^{\prime \prime}-\mathrm{P}_{\mathrm{p}}^{\prime \prime}}},
$$

where $\mathrm{P}_{\mathrm{r}}^{\prime}, \mathrm{P}_{\mathrm{r}}^{\prime \prime}$ - the partial pressure of the absorbed component in the gas phase at the entrance to the apparatus and exit from the apparatus;

$\mathrm{P}_{\mathrm{p}}{ }^{\prime}, \mathrm{P}_{\mathrm{p}}{ }^{\prime \prime}$ - equilibrium partial pressure of the absorbed component above the liquid.

The greater the difference between the pressures, the greater the driving force of the process and the faster the absorption takes place.

Water, as well as organic and inorganic solvents, are used as absorption solutions. For a more complete extraction of the harmful component from the gas mixture, it is necessary to use the principle of countercurrent with a continuous supply of fresh solution to the absorber.

The waste waters of textile enterprises, which will be considered by us as absorbents, are complex physicochemical multicomponent systems containing insoluble impurities, suspensions, molecular solutes of mineral and organic origin. They have a specific color. Chemical oxygen demand (COD) is significantly higher than biological oxygen demand (BOD), which indicates the presence of difficult to oxidize compounds in wastewater. The concentration of synthetic surfactants and certain drugs is in the range of $10-140 \mathrm{mg} / \mathrm{dm}^{3}$.

A significant predominance of alkaline reagents over acidic and neutral (75-80\%), leads to an increase in alkalinity of wastewater with an increase in the activity of the reaction $\mathrm{pH}$ to $11-12.5$.

High alkalinity of wastewater creates certain difficulties in their treatment in the system of city-wide sewage treatment plants, where the main method is biological treatment. The $\mathrm{pH}$ value of wastewater significantly affects the vital activity of microorganisms of activated sludge aerotanks. Studies have shown that with the help of unadapted (active) sludge of aerotanks it is possible to successfully purify wastewater within the limits of the active reaction $\mathrm{pH} 6.5-9.2$ at a temperature of $20^{\circ} \mathrm{C}$. The increase in alkalinity of wastewater above $\mathrm{pH}$ 9.2 causes the death of microorganisms.
In industry, alkaline type absorbers $\left(\mathrm{NaOH}, \mathrm{Na}_{2} \mathrm{CO}_{3}\right.$, $\left.\mathrm{Ca}(\mathrm{OH})_{2}, \mathrm{MgO}\right)$ are used to clean flue gases [7]. For the most cost-effective operation of sewage treatment plants, they are designed taking into account local conditions and the presence of those components that could be used as $\mathrm{SO}_{2}$ absorption solutions. At present, a huge amount of alkaline waste water is discharged into industrial sewage systems.

In wastewater treatment plants, the alkalinity of wastewater is neutralized by mineral acids $\left(\mathrm{HCl}, \mathrm{H}_{2} \mathrm{SO}_{4}\right.$, etc.), which is very expensive. Recently, in many countries, the possibility of using alkaline waste water as a neutralizing agent has been investigated.

Sulfurous anhydride contained in waste gases creates an acidic environment and can be neutralized with alkaline waste water. As a result of the absorption of sulfur dioxide, an acid is formed, which is necessary to neutralize the alkali. Wastewater becomes discolored with ash, which is formed during the combustion of coal in a steam boiler. Fly ash, due to its large surface area and high carbon content (over 40\%), is a good adsorbent.

An analysis of the emissions of harmful substances entering the atmosphere during the operation of the CHP revealed that the maximum surface concentration of sulfur dioxide in them is $1.37 \mathrm{mg} / \mathrm{m}^{3}$. This is 2.74 times the maximum allowable concentration for populated areas.

To study the process of neutralization of waste gases containing sulfur dioxide by sewage, a laboratory installation was created. The studies were conducted on the basis of natural wastewater of a cotton mill and an air mixture containing sulfur dioxide. The task of laboratory research included the study of the influence of various physicochemical factors on the process of cleaning waste gases from $\mathrm{SO} 2$. And also, the identification of optimal neutralization parameters and obtaining a mathematical model of the process

The degree of purification of waste gases from sulfur dioxide depends on many different parameters. The data are shown in table 1.

In order to verify the data obtained in the laboratory, as well as to further simulate the process of neutralizing waste gases with sewage, studies were carried out at a pilot plant using natural gases and sewage.

The main apparatus of the installation is the tore absorber-neutralizer, the design of which is similar to that used in the pilot installation.

The installation consists of an absorber 3, made in the form of a torus apparatus with a diameter of $3 \mathrm{~m}$ and a height of $1.5 \mathrm{~m}$ which has a flat roof and a conical bottom. A central tube 5 is installed in the center of the absorber with a gas outlet 2 . The gas enters the absorber via fitting 6 , which is tangentially welded to the outer side surface of the apparatus. Centrifugal atomizers 4 interconnected by a common collector 7 are placed on the flat roof of the apparatus. Absorbent (wastewater) is supplied to the collector by means of a centrifugal pump 10 with a capacity of $6 \mathrm{~m}^{3} / \mathrm{h}(\mathrm{N}=3.2 \mathrm{~kW})$. 
The scheme adopted a closed irrigation cycle with a continuous supply of fresh solution to the system and the exit from the system of the same amount of neutralized wastewater. Collecting the fluid circulating in the system is carried out in collection 8 , from where part of it goes to the irrigation of the absorber, and part of it is removed from the system and discharged into neutral sewage as neutral wastewater. The flow rate of the liquid supplied for irrigation was carried out using a diaphragm and a differential pressure gauge 9 .

The contact between the liquid and the gas in the absorber was made by spraying the liquid with centrifugal sprays. The atomizer consists of a vertical rotating shaft, on the lower part of which a centrifugal atomizer with blades is mounted. The shaft is driven by an electric motor $\mathrm{N}=0.12 \mathrm{~kW}, \mathrm{n}=2800 \mathrm{~min}^{-1}$. Liquid falling on the blades under the action of centrifugal force is sprayed into small droplets, creating a developed contact surface. The advantage of this method of spraying is the high reliability of operation of the nozzle centrifugal nozzles without clogging them with solid particles (ash). For uniform irrigation of the entire volume of the absorber, it has five centrifugal nozzles with a capacity of $165 \mathrm{~m}^{3} / \mathrm{h}$ each. The purified gases through the central pipe 5 are emitted into the atmosphere. In the pipe, there are drop eliminators 6 in the form of a layer of Rashig rings.

Wastewater was placed in a container 8 and their composition was analyzed. After turning on the centrifugal atomizers and the centrifugal pump 10, gas was supplied to the absorber. After neutralization and settling, sewage was discharged into the sewage system, and the purified gas was released into the atmosphere.

Table 1

Dependence of the degree of gas purification on $\mathrm{SO}_{2}(\beta)$ and degree of neutralization of the absorbent ( $\alpha$ ) on the volume of gas passing through the absorbent

\begin{tabular}{|c|c|c|c|c|c|c|c|c|c|}
\hline \multirow{2}{*}{ № } & \multirow{2}{*}{$\begin{array}{l}\text { Absorption } \\
\text { time, } \\
\text { min }\end{array}$} & \multirow{2}{*}{$\underset{\substack{\text { Gansumption, } \\
\mathrm{dm}^{3} / \mathrm{min}}}{\text {, }}$} & \multirow{2}{*}{$\begin{array}{c}\text { Volume } \\
\text { of gas, } \mathbf{d m}^{3}\end{array}$} & \multicolumn{2}{|c|}{$\begin{array}{c}\text { Concentration } \\
\mathrm{SO}_{2}, \%\end{array}$} & \multirow{2}{*}{$\begin{array}{l}\text { Alkalinity } \\
\text { of the } \\
\text { absorbent, } \\
\text { mg-eq/dm }\end{array}$} & \multirow{2}{*}{$\begin{array}{c}\text { pH } \\
\text { absor- } \\
\text { bent }\end{array}$} & \multicolumn{2}{|c|}{$\begin{array}{c}\text { Cleaning } \\
\text { degree }\end{array}$} \\
\hline & & & & Cin & Cout & & & $\begin{array}{c}\alpha \\
(\%)\end{array}$ & $\begin{array}{c}\beta \\
(\%)\end{array}$ \\
\hline 1 & 0 & & & 0.04 & & 8 & 11.01 & & \\
\hline 2 & 1 & 25 & 25 & 0.04 & 0.0080 & 7 & 10.00 & 83 & 80 \\
\hline 3 & 2 & 25 & 50 & 0.04 & 0.0081 & 7 & 9.50 & 84 & 80 \\
\hline 4 & 3 & 25 & 75 & 0.04 & 0.0083 & 7 & 9.02 & 85 & 79 \\
\hline 5 & 4 & 25 & 100 & 0.04 & 0.0086 & 6 & 8.5 & 86 & 78 \\
\hline 6 & 5 & 25 & 125 & 0.04 & 0.0091 & 6 & 8.05 & 87 & 77 \\
\hline 7 & 6 & 25 & 150 & 0.04 & 0.0096 & 6 & 7.95 & 88 & 76 \\
\hline 8 & 7 & 25 & 175 & 0.04 & 0.0099 & 5 & 7.55 & 89 & 75 \\
\hline 9 & 8 & 25 & 200 & 0.04 & 0.0100 & 5 & 7.10 & 90 & 75 \\
\hline 10 & 9 & 25 & 225 & 0.04 & 0.0105 & 5 & 6.05 & 90 & 74 \\
\hline 11 & 10 & 25 & 250 & 0.04 & 0.0109 & 4 & 6.01 & 91 & 73 \\
\hline 12 & 11 & 25 & 275 & 0.04 & 0.0110 & 4 & 5.55 & 91 & 72 \\
\hline 13 & 12 & 25 & 300 & 0.04 & 0.0115 & 4 & 5.51 & 92 & 71 \\
\hline 14 & 13 & 25 & 325 & 0.04 & 0.0117 & 4 & 5.47 & 92 & 71 \\
\hline 15 & 14 & 25 & 350 & 0.04 & 0.0124 & 4 & 5.41 & 93 & 68 \\
\hline 16 & 15 & 25 & 375 & 0.04 & 0.0131 & 4 & 5.35 & 93 & 67 \\
\hline 17 & 16 & 25 & 400 & 0.04 & 0.0135 & 3 & 5.29 & 94 & 66 \\
\hline 18 & 17 & 25 & 425 & 0.04 & 0.0137 & 3 & 5.15 & 94 & 66 \\
\hline 19 & 18 & 25 & 450 & 0.04 & 0.0141 & 3 & 5.03 & 95 & 64 \\
\hline 20 & 19 & 25 & 475 & 0.04 & 0.0151 & 3 & 5.01 & 95 & 62 \\
\hline 21 & 20 & 25 & 500 & 0.04 & 0.0157 & 3 & 4.94 & 95 & 60 \\
\hline 22 & 21 & 25 & 525 & 0.04 & 0.0161 & 2 & 4.93 & 96 & 59 \\
\hline 23 & 22 & 25 & 550 & 0.04 & 0.0167 & 2 & 4.93 & 96 & 58 \\
\hline 24 & 23 & 25 & 575 & 0.04 & 0.0171 & 2 & 4.92 & 97 & 57 \\
\hline 25 & 24 & 25 & 600 & 0.04 & 0.0174 & 2 & 4.92 & 98 & 56 \\
\hline 26 & 25 & 25 & 625 & 0.04 & 0.0175 & 2 & 4.91 & 99 & 56 \\
\hline 27 & 26 & 25 & 650 & 0.04 & 0.0184 & 2 & 4.91 & 99 & 55 \\
\hline 28 & 27 & 25 & 675 & 0.04 & 0.0185 & 2 & 4.90 & 99 & 54 \\
\hline 29 & 28 & 25 & 700 & 0.04 & 0.0186 & 2 & 4.90 & 100 & 53 \\
\hline 30 & 29 & 25 & 725 & 0.04 & 0.0187 & 2 & 4.90 & 100 & 53 \\
\hline 31 & 30 & 25 & 750 & 0.04 & 0.0189 & 2 & 4.90 & 100 & 53 \\
\hline
\end{tabular}


When conducting research on the installation, the following analytical control was carried out:

in gases, the content of sulfuric anhydride at the inlet and outlet by the iodometric method once an hour, the ash content is episodic;

in wastewater - the content of $\mathrm{NaOH}$, total alkalinity, $\mathrm{pH}$ (every 15 minutes), the total analysis of wastewater (occasionally), ash content (1 time per shift). The temperature of the gas and waste water at the inlet and outlet was constantly monitored. The degree of gas purification was determined by the formula:

$$
\beta \%=\frac{C_{\text {in }}-C_{\text {out }}}{C_{\text {in }}} \cdot 100,
$$

where $\mathrm{C}_{\text {in }}-\mathrm{SO}_{2}$ concentration at the entrance to the apparatus, $\%$ vol.;

$\mathrm{C}_{\text {out }}-\mathrm{SO}_{2}$ concentration at the exit of the apparatus, $\%$ vol.

Acceptable $\mathrm{pH}=6.5-8.5$. Therefore, a 100\% degree of neutralization can be considered if the $\mathrm{pH}$ of the medium is lowered to $\mathrm{pH}=8.5$ and lower, however, not lower than $\mathrm{pH}=6.5$. In studies, the degree of neutralization was assumed to be $100 \%$ in the case when the total alkalinity in the solution was zero.

As a result of the calculations, an equation was obtained describing the process of purifying gases from sulfuric anhydride (implicit form).

$$
\begin{gathered}
y=84,47-0,97 X_{1}+4,97 X_{2}+1,28 X_{3}+2,47 X_{4}+3,03 X_{1} X_{2}+0,094 X_{1} X_{3}- \\
3,59 X_{1} X_{4}-1,59 X_{2} X_{3}+3,09 X_{2} X_{4}-3,34 X_{3} X_{4} .
\end{gathered}
$$

Using the transition formulas, we obtain the equation in its natural form:

$\beta \%=37.84+2.39 \tau-0.86 \mathrm{H}+0.86 \mathrm{t}^{\circ}+29.1 \cdot 10^{-3} \mathrm{~W}+$

$0,14 \tau \mathrm{H}+1.1 \cdot 10{ }^{3} \mathrm{HW}+1.79 \cdot 10^{-3} \tau \mathrm{t}^{\circ}-2.99 \cdot 10^{-3} \tau \mathrm{W}-$

$12.9 \cdot 10^{-3} \mathrm{Ht}^{\circ}-0.477 \cdot 10^{-3} \mathrm{t}^{\circ} \mathrm{W}$

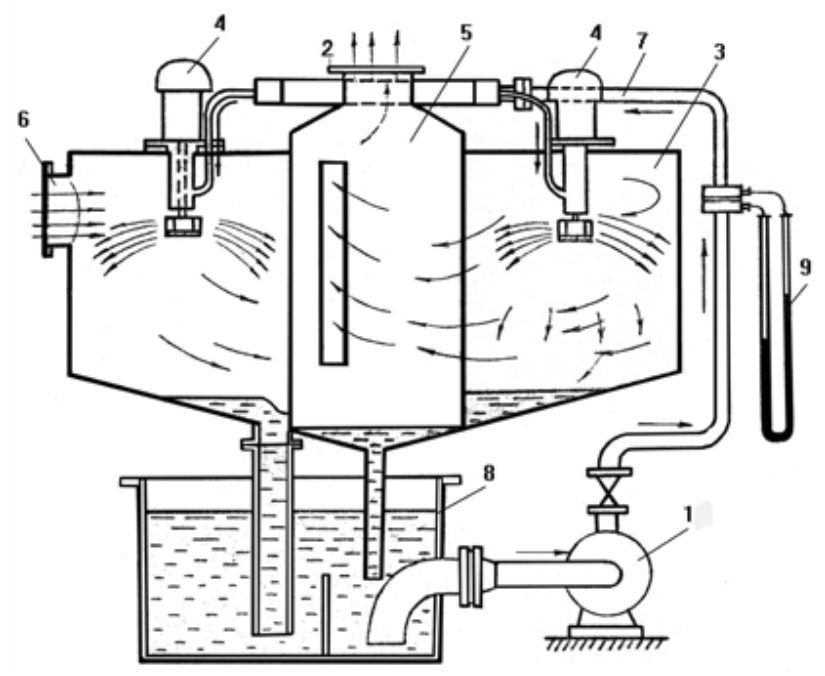

Picture 1. Absorber

1 - pump; 2 - outlet fitting; 3 - absorber; 4 - centrifugal atomizers; 5 - central tube; 6 - input tangential choke;

7 - collector; 8 - water collection; 9 - pressure gauge.

Rejecting the insignificant terms of the equation, we arrive at the desired mathematical model of the process of gas purification from sulfur dioxide in the laboratory setup:

$$
\begin{gathered}
\beta \%=37.84+2.39 \tau-0.86 \mathrm{H}+0.86 \mathrm{t}^{\circ}+ \\
29.1 \cdot 10^{-3} \mathrm{~W}+0.14 \tau \mathrm{H}-2.99 \cdot 10^{-3} \tau \mathrm{W}+ \\
1.1 \cdot 10^{-3} \mathrm{HW}-0.477 \cdot 10^{-3} \mathrm{t}^{\circ} \mathrm{W} .
\end{gathered}
$$

Based on the experimental data, the influence of var-

\begin{tabular}{|c|c|c|c|c|c|c|c|}
\hline \multirow{3}{*}{$\begin{array}{c}\text { № } \\
\text { experience }\end{array}$} & \multicolumn{4}{|c|}{ Factors } & \multirow{2}{*}{\multicolumn{3}{|c|}{ Degree of gas cleaning }} \\
\hline & $X_{1}$ & $\mathbf{X}_{2}$ & $\mathbf{X}_{3}$ & $\mathbf{X}_{4}$ & & & \\
\hline & $\mathbf{t}$ & $\mathbf{H}, \mathbf{s m}$ & $t,{ }^{\circ}$ & $\mathbf{W}, \mathbf{h}^{-1}$ & $\mathbf{y}_{1} \%$ & $\mathbf{y}_{2} \%$ & $\mathbf{y}_{3} \%$ \\
\hline 1 & 1 & 3 & 25 & 1000 & 71 & 67 & 69 \\
\hline 2 & 7 & 3 & 25 & 1000 & 75 & 72 & 73.5 \\
\hline 3 & 1 & 17 & 25 & 1000 & 81 & 79 & 80 \\
\hline 4 & 7 & 17 & 25 & 1000 & 90 & 84 & 87 \\
\hline 5 & 1 & 3 & 60 & 1000 & 83 & 85 & 84 \\
\hline 6 & 7 & 3 & 60 & 1000 & 96 & 92 & 94 \\
\hline 7 & 1 & 17 & 60 & 1000 & 85 & 84 & 84.5 \\
\hline 8 & 7 & 17 & 60 & 1000 & 81 & 87 & 84 \\
\hline 9 & 1 & 3 & 25 & 1800 & 93 & 95 & 94 \\
\hline 10 & 7 & 3 & 25 & 1800 & 67 & 73 & 70 \\
\hline 11 & 1 & 17 & 25 & 1800 & 93 & 95 & 94 \\
\hline 12 & 7 & 17 & 25 & 1800 & 99 & 97 & 98 \\
\hline 13 & 1 & 3 & 60 & 1800 & 90 & 84 & 87 \\
\hline 14 & 7 & 3 & 60 & 1800 & 66 & 63 & 64.5 \\
\hline 15 & 1 & 17 & 60 & 1800 & 92 & 90 & 91 \\
\hline 16 & 7 & 17 & 60 & 1800 & 98 & 96 & 97 \\
\hline
\end{tabular}
ious factors on the degree of purification of waste gases and the degree of neutralization of wastewater has been established.

Table 2

The working matrix of the process of neutralizing gases from sulfuric anhydride 
Calculated matrix for determining the coefficients of the equation for the process of gas purification from sulfuric anhydride

\begin{tabular}{|c|c|c|c|c|c|c|c|c|c|c|c|}
\hline \multirow{2}{*}{$\begin{array}{c}\text { № } \\
\text { experience }\end{array}$} & \multicolumn{10}{|c|}{ Estimated coefficients } \\
\cline { 2 - 14 } & $\mathbf{B}_{\mathbf{0}}$ & $\mathbf{B}_{\mathbf{1}}$ & $\mathbf{B}_{\mathbf{2}}$ & $\mathbf{B}_{\mathbf{3}}$ & $\mathbf{B}_{\mathbf{4}}$ & $\mathbf{B}_{\mathbf{1 2}}$ & $\mathbf{B}_{\mathbf{1 3}}$ & $\mathbf{B}_{\mathbf{1 4}}$ & $\mathbf{B}_{\mathbf{2 3}}$ & $\mathbf{B}_{\mathbf{2 4}}$ & $\mathbf{B}_{\mathbf{3 4}}$ \\
\hline 1 & 69 & -69 & -69 & -69 & -69 & 69 & 69 & 69 & 69 & 69 & 69 \\
\hline 2 & 73.5 & 73.5 & -73.5 & -73.5 & -73.5 & -73.5 & -73.5 & -73.5 & 73.5 & 73.5 & 73.5 \\
\hline 3 & 80 & -80 & 80 & -80 & -80 & -80 & 80 & 80 & -80 & -80 & 80 \\
\hline 4 & 87 & 87 & 87 & -87 & -87 & 87 & -87 & -87 & -87 & -87 & 87 \\
\hline 5 & 84 & -84 & -84 & 84 & -84 & 84 & -84 & 84 & -84 & 84 & -84 \\
\hline 6 & 94 & 94 & -94 & 94 & -94 & -94 & 94 & -94 & -94 & 94 & -94 \\
\hline 7 & 84,5 & $-84,5$ & $-84,5$ & 84,5 & $-84,5$ & $-84,5$ & $-84,5$ & 84,5 & 84,5 & $-84,5$ & $-84,5$ \\
\hline 8 & 84 & 84 & 84 & 84 & -84 & 84 & 84 & -84 & 84 & -84 & -84 \\
\hline 9 & 94 & -94 & -94 & -94 & 94 & 94 & 94 & -94 & 94 & -94 & -94 \\
\hline 10 & 70 & 70 & -70 & -70 & 70 & -70 & -70 & 70 & 70 & -70 & -70 \\
\hline 11 & 94 & -94 & 94 & -94 & 94 & -94 & 94 & -94 & -94 & 94 & -94 \\
\hline 12 & 98 & 98 & 98 & -98 & 98 & 98 & -98 & -98 & -98 & 98 & -98 \\
\hline 13 & 87 & -87 & -87 & 87 & 87 & 87 & -87 & -87 & -87 & -87 & 87 \\
\hline 14 & 64,5 & 64,5 & $-64,5$ & 64,5 & 64,5 & $-64,5$ & 64,5 & 64,5 & $-64,5$ & $-64,5$ & 64,5 \\
\hline 15 & 91 & -91 & 91 & 91 & 91 & -91 & -91 & -91 & 91 & 91 & 91 \\
\hline 16 & 97 & 97 & 97 & 97 & 97 & 97 & 97 & 97 & 97 & 97 & 97 \\
\hline $\mathrm{B}_{\mathrm{i}}$ & 84.47 & -0.97 & 4.97 & 1.28 & 2.47 & 3.03 & 0.094 & -3.59 & -1.59 & 3.09 & 3.34 \\
\hline
\end{tabular}

The effect of volumetric rate on the degree of gas purification and degree of neutralization of wastewater. Under the volumetric rate, we take the volume of gas passing through $1 \mathrm{~m}^{3}$ of the volume of the apparatus. With increasing volumetric rate, the degree of gas purification decreases. This is due to the decrease in the residence time of the gas in the apparatus, i.e. reducing the time of contact of the gas with the liquid. To achieve a high degree of gas purification (within $90 \%$ ), the gas volumetric rate should not exceed $500-750 \mathrm{~h}^{-1}$.

Influence of irrigation density on the degree of gas purification and the degree of neutralization of wastewater.Irrigation density shows the volume of irrigating fluid passing through $1 \mathrm{~m}^{2}$ of the apparatus cross-section per unit time $\mathrm{P}, \mathrm{m}^{3} / \mathrm{m}^{2} \cdot \mathrm{h}$.

A change was also made in the amount of fluid supplied for irrigation into the apparatus. The wastewater flow rate at the installation varied in the range from $2.4 \mathrm{~m}^{3} / \mathrm{h}$ to $7.7 \mathrm{~m}^{3} / \mathrm{h}$, which corresponds to the irrigation density, $0.6-1.91 \mathrm{~m}^{3} / \mathrm{m}^{2} \cdot \mathrm{h}$.

With an increase in the irrigation density, the degree of gas purification increases, and this dependence is most pronounced with a short circulation time $(15 \mathrm{~min})$. When the irrigation density doubles, from 1 to $2 \mathrm{~m}^{3} / \mathrm{m}^{2} \cdot \mathrm{h}$, the degree of gas purification increases from 72 to $90 \%$, i.e. by $18 \%$. Therefore, in production processes, for a more complete purification of gases, it is necessary to increase the density of irrigation. A high degree of gas purification cannot be achieved with a simultaneous high degree of neutralization of wastewater.

The influence of the circulation time of the solution on the degree of gas purification and the degree of neu- tralization of wastewater. Circulation time is the time of the solution, without adding to it a fresh solution and removal of used.

At the beginning of the research, wastewater has the highest alkalinity and maximum $\mathrm{pH}$. As the solution circulates, the alkaline components of the wastewater react with $\mathrm{SO}_{2}$ and their content gradually decreases to complete conversion to sulfite-sulphate salts. At the same time, the $\mathrm{pH}$ of these solutions also decreases.

Alkaline wastewater absorbs $\mathrm{SO}_{2}$ from waste gases better than those solutions that have been in circulation for 30 or 40 minutes. The common alkalinity decreases to zero already after about 15 minutes of circulation, after which the absorption of $\mathrm{SO}_{2}$ occurs already in a weakly alkaline or weakly acidic medium. When $\mathrm{SO}_{2}$ is absorbed by sewage having an initial $\mathrm{pH}=11.75$, when the circulation time is 15 minutes, the degree of gas purification reaches $90 \%$, but after 30 minutes it decreases to $85 \%$ and after 60 minutes to $70 \%$. The study shows that full $100 \%$ neutralization occurs at the circulation time for wastewater with $\mathrm{pH}=10.1$ after 32 minutes, and with $\mathrm{pH}=11.0$ after 48 minutes.

It should be noted that for $100 \%$ degree of neutralization the conditions were accepted, when the total alkalinity of the wastewater was zero, while the $\mathrm{pH}$ of the wastewater was in the range of 5-6. This indicates that wastewater has a weakly acidic environment. Therefore, in practical terms, it is sufficient to carry out neutralization by $70-80 \%$, which will comply with the MPC (Maximum permissible concentration) standards. Thus, the circulation time of the solution should be 15-25 minutes, after which the wastewater can be discharged into the reservoir. 
The effect of the initial concentration of $\mathrm{SO}_{2}$ on the degree of gas purification. Thermal power plant exhaust gases have non-constant $\mathrm{SO}_{2}$ concentration. Usually the concentration of $\mathrm{SO}_{2}$ in the exhaust gas ranges from 0.04 to $0.08 \%$. The data show that with increasing concentration, the degree of gas purification increases.

To study the process of neutralization of waste gases with sewage, studies have been conducted at a pilot plant using natural gases and sewage. In waste gases, the was degreed of neutralization of sulfurous anhydride and ash is determined, and in wastewater - the $\mathrm{NaOH}$ content, total alkalinity, and $\mathrm{pH}$.

Was make matrices for determining the coefficients of the equation have been compiled and an equation has been obtained that describes the process of cleaning gases from sulfuric anhydride.

The influence of various factors on the degree of purification of waste gases and the degree of neutralization of wastewater has been established.

\section{References}

1. ASHRAE 62-1999 "Ventilation for Acceptable Indoor Air Quality".

2. URL: https://ru.wikipedia.org/wiki/Загрязнение_атмосферы_Земли.

3. URL: http://www.eco.nw.ru/lib/data/04/4/030404.htm.

4. Васильев Б.Т., Отвагина М.И. Технология серной кислоты. Москва, 1985.

5. URL: https://moodle.ggau.by/mod/page/view.php?id=2923.

6. Young D.M., Crowell A.D. Physical adsorption of gases. L., 1962. 